Geographical Magazine

\title{
Green harbour, Spitsbergen
}

\section{Gunnar Isachsen}

To cite this article: Gunnar Isachsen (1915) Green harbour, Spitsbergen, Scottish Geographical Magazine, 31:1, 1-22, DOI: 10.1080/14702541508555181

To link to this article: http://dx.doi.org/10.1080/14702541508555181

曲 Published online: 30 Jan 2008.

Submit your article to this journal $\pi$

LII Article views: 8

Q View related articles $₫$

4 Citing articles: 4 View citing articles 


\title{
THE SCOTTISH
}

\section{GE OGR A P H I C A L}

\author{
MAGAZT NE.
}

\section{GREEN HARBOUR, SPITSBERGEN. ${ }^{1}$}

By Gunnar Isachsen.

\section{(With Sketch-Map and Illustrations.)}

Grem HARBOUR ${ }^{2}$ (Green Bay) runs up in a south-easterly direction on the south side of Ice Fjord, Spitsbergen, at a distance of about $10 \mathrm{~km}$. from the mouth of the fjord. It has waited a long time to be mapped, although this fjord has been one of the most frequently visited in Spitsbergen. In 1891 and 1892, Prince Henry of Bourbon had a rapid sketch ${ }^{3}$ of the fjord made from his yacht, the Flentr de Lys, and this, in 1899, was inserted in the British Admiralty chart of the anchorages on the west coast of Spitsbergen. The value of this sketch has been indicated by De Geer," who mentions, inter alia, that "when trying to identify a glacier which on the sketch of Green Bay von Barry had named after the Princess Aldegonda von Bourbon, born Braganza, I found that the photo, Plate VI. at p. 30 , said to represent this glacier, was in reality from Magdalena Bay."

In 1910, Professor G. De Geer's "Geological Map of Central Spitsbergen," scale $1: 200,000$, was published for the Eleventh International Geological Congress, held in Stockholm, and in 1912 his "Map of Central Spitzbergen with the main coal-district," scale $1: 300,000$, was issued. Green Harbour appears on De Geer's maps for the first time as the result of real map-work. While the sketch-map accompanying this article

1 Translated from the Norwegian by Miss Jessie Muir. We are indebted to the Norwegian Geographical Society, Christiania, for the loan of the blocks of Figs. 1, 2,3 and 4.Ed. S.G.M.

2 G. Isachsen: Green Harbour. Det norske geografiske Selskabs Aarbok, xxiv., 1912-13, pp. 151-162. Christiania, 1913.

R. Ritter von Barry: Zwer Fahrten in das nördliche Eismeer nach Spitzbergen und Novaja Zemlja, unternommen von Prinz Heinrich von Bourbon. Pola, 1894.

VOL XXXI. 
was being prepared, I received De Geer's map of 1912, but unfortunately not in time to permit of the adoption throughout of its nomenclature.

In the old whaling days in Spitsbergen, the vessels did not go far up the fjords before anchoring and getting to work, and therefore, as the upper parts of the fjords were of small interest to the whalers, the question of fjord or sound long remained unsolved, a fjord being frequently taken for a sound, and vice versa. The name "sound" was given -and still is - to the fjords Bell Sound and Horn Sound, and Foreland Sound was long called Forland Fjord (Voorlands fioerd).

On Barents' map-which was published in 1598 and 1599 by Cornelius Claesz in the second part of the abbreviated Latin edition of Linschoten's Itinerarium-Ice Fjord was called Grooten Inwyck. This name also occurs on Wright's map (1600) and on Hondius' map (1611). On Daniel's map (1613) the fjord is called Y sse Sond, and on that of Caesins (1622), $Y_{S}$ sond. On the last-mentioned map, presumably for the first time, Green Harbour is marked as Groenhaven. On the Muscovy Company's chart (1625), we find Ice sounde and Greene harboure; on Middelhouen's chart, No. 2 (1634), Is Sondt and Green Haven; on Blaeu's map (about 1662), Ice Fjord is called Groenhaven; and on Doncker's (1663) wo find Groene haven, while Ice Fjord has no name. On Seller's map (1671) we find Yse Sound and Groene Harbour ; on that of Giles and Rep (about 1710), Ys Sond, and below the name Fioord van Groene herberg. Green Harbour is called Graene Herberg of Greene Haven. ${ }^{1}$ Zordrager's map (1720) gives Eys Sond Bay and Griine Herberg; and Scoresby's (1820) has Green Harbour. De Geer's map (1912) has Green Bay. ${ }^{2}$

It was the English skipper, Jonas Poole, who in 1610 gave the name of Green Haven ${ }^{3}$ to the fjord. Poole had been sent out by the Muscovy Company with the Amitie, a small vessel of seventy tons, for the purpose of hunting and exploration. On 21 st May he was right off Ice Fjord. As ice blocked the fjord, he made a cruise northwards and visited Cross Bay. Bears were plentiful in those days. In Cross Bay, for instance, the party brought down ten bears in one day. On 26th June Poole went into Ice Fjord, and anchored in Green Harbour on the 27th. He did not go out again until the 5th July, when he again sailed northwards to Cross Bay and King's Bay. In the latter fjord Poole found "seacoales which burnt very well." The result of Poole's hunting that summer was 120 walruses, 51 reindeer, 33 bears, and a large quantity of whalobone which was gathered on the shore.

In 1612 a Spanish vessel from San Sebastian took a full eargo of whale in Green Harbour. The vessel was piloted to the harbour by Nicholas Woodeock, who had been to Spitsbergen the year before with a ship from Hull. He was rewarded for his labour in guiding a ship of another nation up to the whaling-ground with sixteen months' imprisonment in the Tower.

In 1613 a large number of ressels were whaling off Spitsbergen, and

\footnotetext{
I G. De Geer: The Coal Region of Central Spitzbergen. Ymer, h. 3. Stockholm, 1912

2 Norwegian whalers still often call the fjord Grönherberg.

s M. Conway: No Man's Land. Cambridge, 1906.
} 


\section{GREEN HARBOUR THE ISACHSEN SPITSBERGEN EXPEDITION $1909 \cdot 1910$}

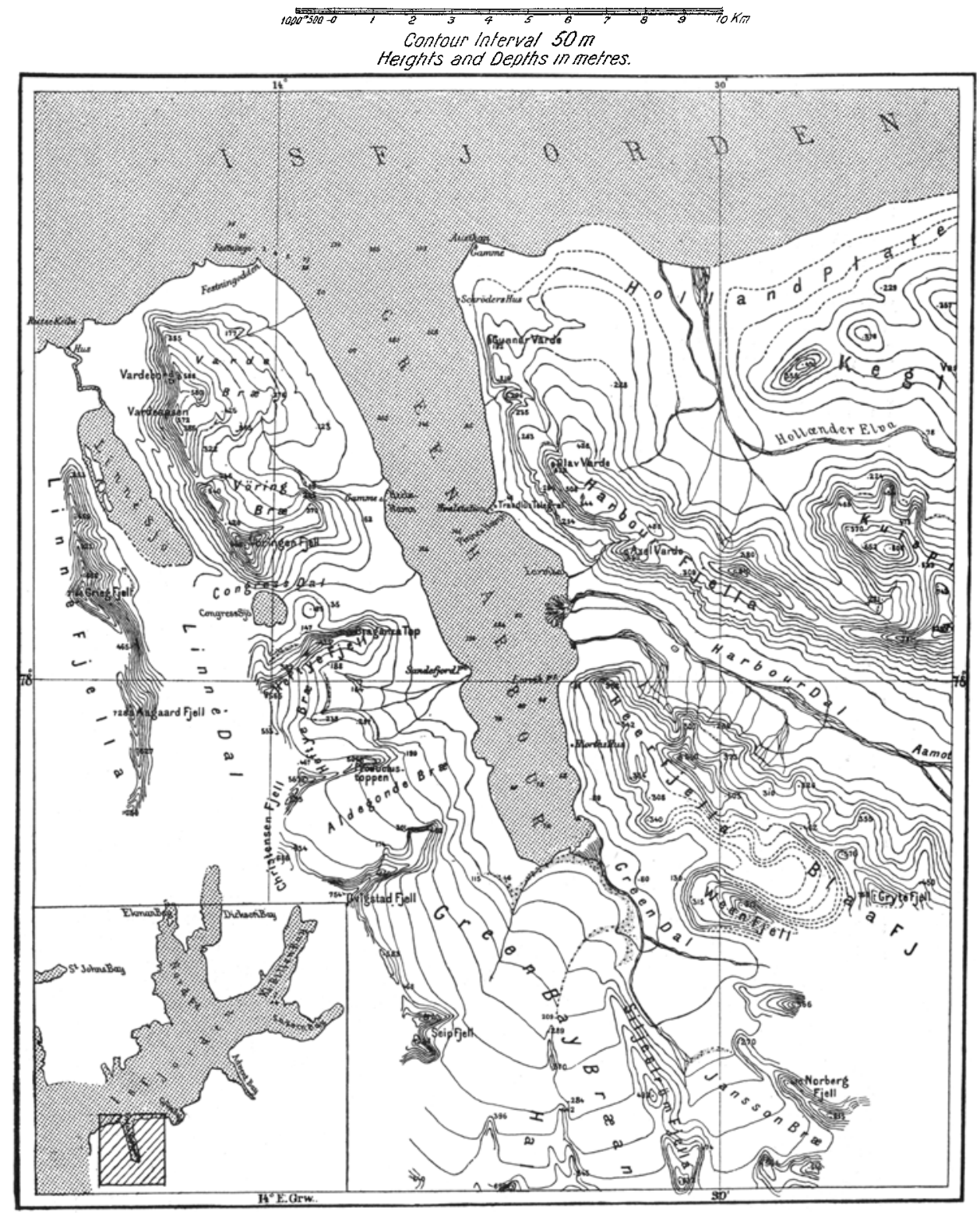

Explcunation.-.-The following are the chief Norwegian terms used on the map :-Aas =hill ; Bræ=glacier; Dal $=$ valley ; Elv=river ; Fjell=mountain ; Gamme=a hut; Hamn=haven; Hus=house ; Kap or Odde=Cape, Point ; Keile=creek ; Sjo=lake ; Top=peak ; Varde=cairn; Vik=bay. 
several of them made full cargoes in Green Harbour. Most of the vessels there were English, and they tried to keep other nations away. A French ship, the Jacques, of Bordeaux, was, however, allowed to try her luck there on condition that the English had the first eight whales killed by the French ship. The latter killed twelve in all.

Sometimes, however, the Dutch fished in this fjord. In 1616, for instance, a Dutch whaler was in Green Harbour after having fished off Jan Mayen. Ice Fjord was not considered so good a whaling-ground, however, as Bell Sound and Horn Sound; but the ice conditions were better in the former than in the two latter.

Towards the close of the seventeenth century whales had to be sought out at sea, so the bay fishery ceased almost entirely. It was usual, however, at the end of the expedition to put into some Spitsbergen harbour to clean up and to hunt reindeer. Green Harbour was frequently visited for these purposes.

Russians often wintered in Green Harbour in the eighteenth century. In 1826 the Russian Staratschin died in Green Harbour, after having wintered in Spitsbergen for thirty-nine years. Norwegian hunters wintered in Green Harbour in the winter of $1822-23$ and the two following winters, their number in the two last years being twenty-two. There was both a Russian and a Norwegian hut. ${ }^{1}$

On entering Ice Fjord from the south, we see Mount Grieg (778 m.) on the south side of the fjord, and behind it a similar mountain, Mount Vardeborg $(588 \mathrm{~m}$.). Both slope evenly down on the north side towards the coast plain which, to the north and west of the Linne Mountains, is over $3 \mathrm{~km}$. wide, while to the north and east of Mount Vardeborg its width is only from 1 to 2 kilometres.

Between the two above-mentioned mountains runs the Linne Valley in a southerly direction, about $2 \mathrm{~km}$. in width; and at its upper end lies the Linne Glacier. The north part of the valley is occupied by Lake Linné, which is about $5 \mathrm{~km}$. in length and about $1 \mathrm{~km}$. wide. A river runs from the north end of the lake out into Russe Keila.

In turning from mid-channel in Green Harbour and going up the fjord, one notices several glaciers on the west side and at the head of the fjord, whereas there are none visible on the east side. At the extreme north is Varde Glacier, which ends at an altitude of about 150 $\mathrm{m}$. To the south, north of Mount Vöringen $(668 \mathrm{~m}$.), lies the Vöring Glacier, which terminates at an altitude of about $100 \mathrm{~m}$. The stream from the first of these glaciers runs into Green Harbour a couple of kilometres to the south of Festningen Island, while that from the second glacier mentioned runs out at Point Hecla.

South of Mount Vöringen runs Congress Valley at a height of about $100 \mathrm{~m}$., from Green Harbour to Linné Valley. At about its highest point is Congress Lake, which is almost circular, and measures about $1 \mathrm{~km}$. across. The lake's outlet is towards the east, its water flowing into Green Harbour on the north side of the promontory lying southwest of sounding 114 .

1 B. M. Eeilhau : Reise $i \phi s t$-og Vest-Finmarken samt tit Beeren Eiland og Spitsbergen i Aarene 1827 og 1828, Christiania, 1831. 

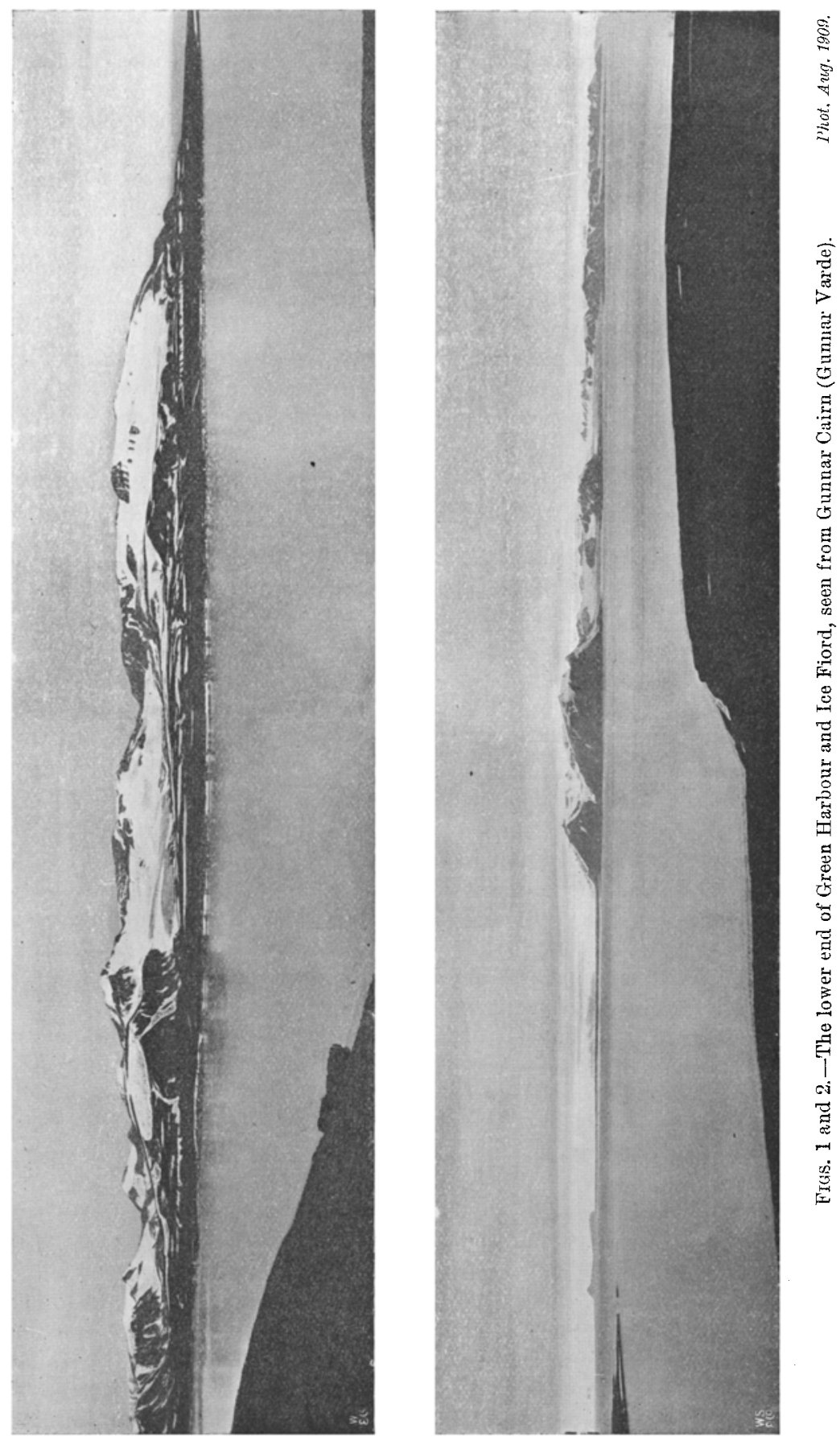
To the south of Congress Valley stands Mount Heftye (372 to $553 \mathrm{~m}$.), with Heftye Glacier descending on its south and east sides, the north branch ending at a height of about $200 \mathrm{~m}$., the south at about $150 \mathrm{~m}$. The streams from these glaciers unite and fall into Green Harbour at Sandefjord Point.

On the south and east of Mount Christensen, 563 to $686 \mathrm{~m}$., Aldegonde Glacier descends right into Green Harbour, 1 to $2 \mathrm{~km}$. to the south of Sandefjord Point.

The name of Green Bay Glacier has been given to the three or four glaciers that converge towards the head of Green Harbour. The western and northern branches, between the mountains Quigstad $(754 \mathrm{~m}$.) and Seip $(728 \mathrm{~m}$.), end at a height of about $50 \mathrm{~m}$., while the middle branch between Mount Seip and the Halland Mountains goes almost down to the sea. The lower part of this branch turns in a nortb-easterly direction towards Green Valley. The most easterly and southerly of these great glacier arms descend between the Halland and the Siljeström Mountains, and terminates, together with the middle branch, in Green Valley. The streams from the two last-mentioned branches unite with that from the Jansson Glacier farther east, and fall into the upper end of Green Harbour.

On the east side of the fjord the cliffs rise evenly in small terraces southwards from the mouth as far as east of Finnes Harbour, where the flat-topped Harbour Mountain rises abruptly from about $300 \mathrm{~m}$. to almost double that height. The Harbour Mountains run in a southeasterly direction on the north side of Harbour Valley, a valley from 2 to $3 \mathrm{~km}$. in width, through which flows the Harbour River with its numerous tributaries and branches.

On the south side of Harbour Valley are the Heer Mountains, running south-east from Larvik Point in two terraces $(352 \mathrm{~m}$. and $640 \mathrm{~m}$.), then sinking, inland, to the north of Mount Ween, to rise once more in Gryte Mountain $(758 \mathrm{~m}$.). To the east of the last-named mountain, and separated from it by Skar Valley, stands Skavl Mountain (700 to $848 \mathrm{~m}$.), on whose north side the Tunge Glacier descends in two tongues to within $200 \mathrm{~m}$. of sea-level.

To the east of the Harbour Mountains, between two branches of the Hollænder River, are the Kulspids Mountains with Mount Fossil $(825 \mathrm{~m}$.$) .$

To the north of these mountains and west of Laila Valley, which runs down to Coles Bay, lie the Kegle Mountains, with their conspicuous summits, Vestal $(658 \mathrm{~m}$.), Vesur $(742 \mathrm{~m}$.), Nox $(801 \mathrm{~m}$.$) , and Vesle$ Keglefyell $(806 \mathrm{~m}$.$) . To the south of the last-named mountain, at the$ south-east end of the Kulspids Mountains, stands the highest hill within the area mapped-Mount Björnson $(926 \mathrm{~m}$.).

East of Laila Valley, lying north and south, is Mount Holmsen, which on the south rises to an altitude of $686 \mathrm{~m}$. , and on the north descends abruptly from the Altar, a flat terrace $350 \mathrm{~m}$. above sea-level, down to the delta in Coles Bay.

On the east side of Mount Holmsen is Coles Valley, running in an east-south-easterly direction. 
Very nearly all the glaciers are situated, as will be seen from the map, on the east of Green Harbour, on the northern and eastern slopes of the mountains drained by the Harbour, Hollænder, and Laila Rivers.

From Mijen Bay in Bell Sound there is a pass to Green Harbour unimpeded by ice, through the Conway, Pas, and Harbour Valleys. While there was no ice on the watershed here, which lies at a height of about $200 \mathrm{~m}$. above the sea, on August 5, 1909, there were huge snowdrifts lying on the somewhat higher watershod between Skar Valley and Berzelius Valley on August 14, 1909 ; but these may possibly disappear in a good summer. ${ }^{1}$ From Conway Valley in Mijen Bay there are several valleys more or less free from ice running across to Coles Bay. These valleys have often been traversed by Norwegians on hunting expeditions, or, when ice conditions were bad in the autumn, in crossing to Ice Fjord, which as a rule is open longer than Bell Sound.

Among the glaciers forming a continuous glacier-covering between Green Harbour and Bell Sound (Mijen Bay) may be mentioned the central branch of the Green Bay Glacier and Erdmann Glacier, which terminates a few kilometres north of Muyden Haven in Bell Sound. From sea to sea there is a very goad glacier-crossing over the Green Bay and Frithjof Glaciers to Mijen Bay due north of Axel Island. This

1 G. Holmsen : Beretning om en geologisk expedition til Spitsbergen, 1909.

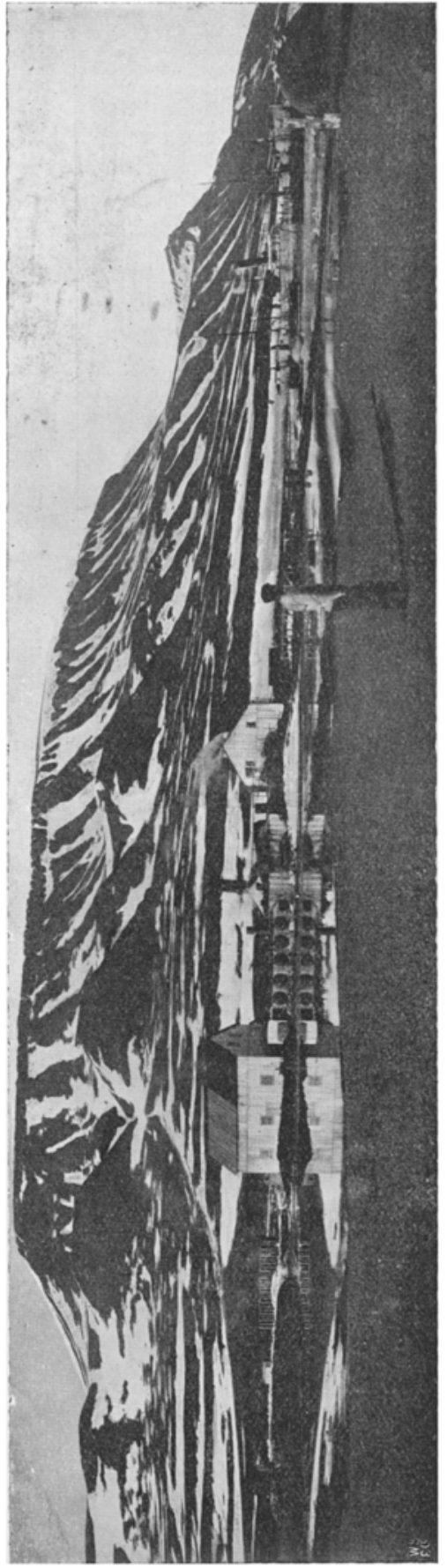
Bergens Museums Aarbok, 1911, No, 9. 


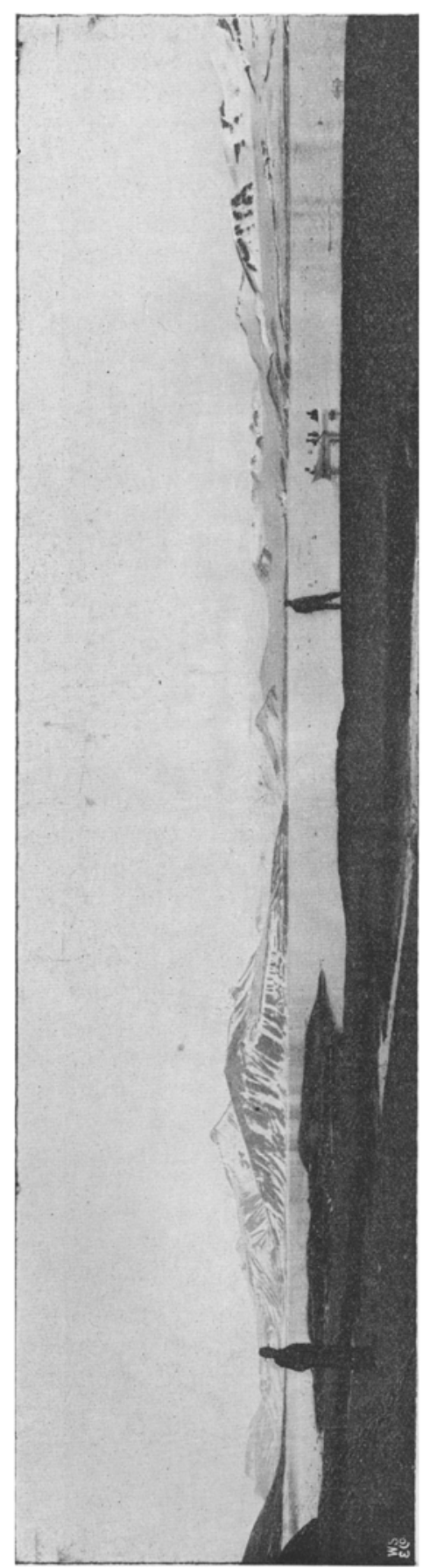

(. passage was made two or three times during Isachsen's expedition in 1910 in six hours. The two glaciers mentioned were free from crevasses and easy to cross. The divide, between the Marcussen and Vasskil.Mountains, lies at an altitude of about $400 \mathrm{~m}$. As in this, the shortest and easiest glacier-crossing between Bell Sound and Ice Fjord, there is not the same probability of meeting with game as in the ice-free valleys east of it, it is natural that hunters should not have taken the glacier-crossing, but preferred to keep to the longer way over the bare land to the east.

According to Holtedahl, ${ }^{1}$ the land to the east of Green Harbour consists of coal-bearing Tertiary sandstone lying in almost horizontal layers. There are also Tertiary beds on the west side in the area farthest north along the coast, while the greater part of the districts nearest the coast consist of slate and sandstone, here and there fossiliferous, belonging to the Jura and Triassic formations. The high chain of mountains in the west consists of beds of flints and limestone of Carboniferous age. On the west side the dip is always steep towards the east. The margin of low-lying land surrounding the coast in Green Harbour and elsewhere is generally not very broad nor especially level. On the west side there are large gravelly terraces upon the flat. In many

$1 \mathrm{G}$. Isachsen: The Hydrographic Observations of the Tsachsen Spitsbergen Excpedition, 1909-10, Kristiania, 1912 ; and 0 . Holtedahl: Zur Kenninis der Karbonablagerungen des westichen Spitzbergens, II, Kristiania, 1913. 
places the mountains have a rather precipitous slope towards the sea. The greater part of the fjord-coast bears cliffs, generally not many metres in height; and it is only at projecting points and at the head of the fjord, in front of the huge moraine heaps deposited by the great glacier, that an even sandy shore is found. In the delta at the mouth of the river in Harbour Valley, south of Axel Cairn, and in that of the river to the east of Green Bay Glacier, the water over this sand or mud beach is shallow for a very long way out. The outermost part of Finnes consists of sandbanks piled up by tidal currents. A lagoon is enclosed within these sandbanks.

Green Harbour is $17 \mathrm{~km}$. long, $5 \mathrm{~km}$. broad at the mouth, and $2 \mathrm{~km}$. at the head. The fjord has a straight course, and diminishes evenly in width from mouth to head, except for the inlet Larvika, in the middle of the east side, which is $3.5 \mathrm{~km}$. broad and about $1 \mathrm{~km}$. deep, and for two or three smaller bays nearer the head on the same side. On the west side of the fjord there is a slight indentation, Hecla Harbour, and a couple of bays nearer the head to the south of Sandefjord Point.

The middle, inner part of the fjord ${ }^{1}$ has a depth of about 78 m., with a low bar at a depth of nearly $60 \mathrm{~m}$. between Larvik Point and Aldegonde Glacier. North of this and almost up to the mouth is the deepest part of the fjord, $141 \mathrm{~m}$., terminating in a low bar at a depth

1 The Hydrographic Observations of the Isachsen Spitsbergen Expedition, 1909-10. Kristiania, 1912.

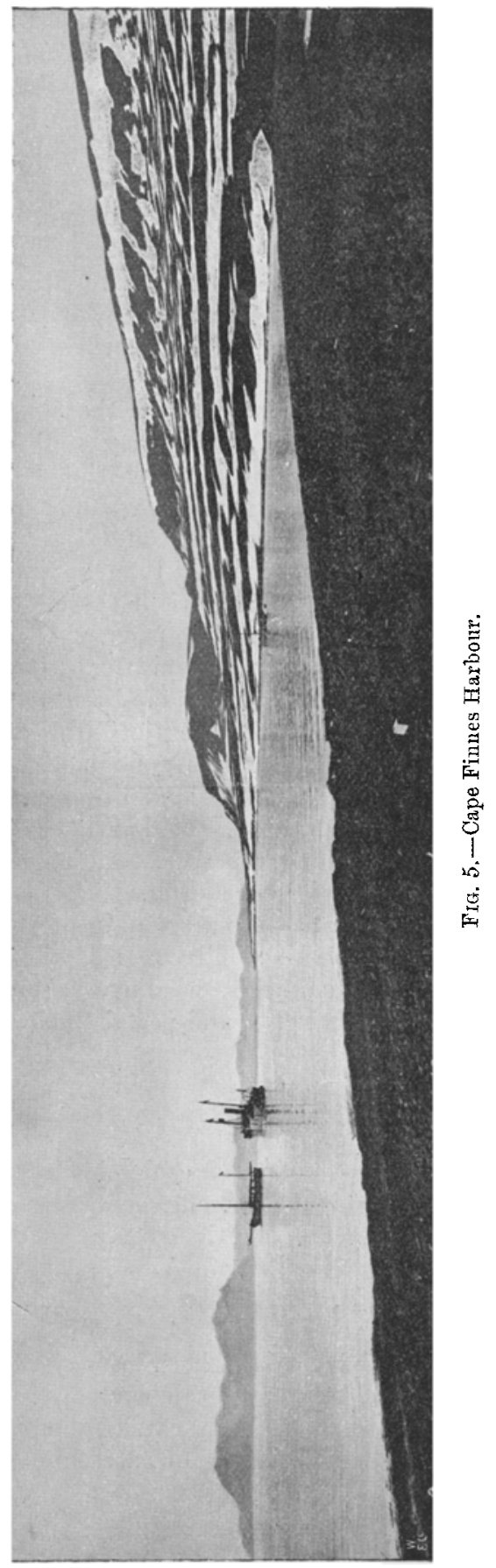


of $127 \mathrm{~m}$, west of Gunnar Cairn. From this bar the bottom sinks evenly outwards to a depth of $165 \mathrm{~m}$. in the middle, at the mouth of the fjord, and continues outwards into the deep water of Ice Fjord. Apart from the deep channel in the middle of the fjord, the greatest depths to the south of and within the last-mentioned bar are along the west shore, while north of it they are nearest the east shore. The fairway outside Cape Festningen, east of the little island of the same name, is foul, and vessels should therefore take the middle of the fjord before turning in. In any case they should not come within one kilometre of the island. East of Festningen Island on the map, three soundings are marked, 2,4 , and 28. The last of these is incorrect: it should be 8 .

Hecla Harbour lies on the west side of the fjord, $7 \mathrm{~km}$. from its mouth. The anchor may well be dropped off the hut, which is easy to discern on nearing the anchorage. There is good holding ground of clay. It is also possible to anchor on the north side of Point Hecla, off which, as also off Cape Finnes on the east side, the depths are considerably greater than at the sides of the promontory. Water may be taken from the river there. Hecla Harbour is the station of the Norwegian Whaling Company, "Alfa \& Beta," of Sandefjord.

Finnes Harbour is on the east side of the fjord, $8 \mathrm{~km}$. from the mouth. There is anchorage both north and south of the cape. If there is much drift-ice in the fjord, the anchorage is uncertain, as the tide runs strong. There is good holding-ground, clay and mud. On the south side of the headland lies the station of the Norwegian Whaling Company "Nimrod," of Larvik. Water may be obtained from the whaling-station's pipes. At a distance of $300 \mathrm{~m}$. from the station is the Norwegian wireless station.

Most of the Norwegian interests and business in Spitsbergen are centred in and around Green Harbour, these interests being in connection with coal-fields, whaling, fishing, hunting, tourist traffic, and the Norwegian wirele'ss and postal stations.

\section{COAL-FIELDS. ${ }^{1}$}

The first claims on coal-fields in Green Harbour by Norwegians were made in 1900. Among companies formed on these and subsequent claims may be mentioned Kulkompagniet Isefjord, Det norske Spitsbergen Kulkompagni, A/S Kulspids, the Norwegian Green Harbour Coal Co., etc. Americans have also claimed land in Green Harbour (Ayer \& Longyear). As many of these claims overlap one another, disputes have arisen, both between Norwegian companies, and between them and the American company. Negotiations between the various companies have been carried on of late years, and are still going on, for the purpose of arriving at a reasonable solution of the difficulties.

I See also Dr. Rudmose Brown's article in vol. xxviii., p. 561.-Ed. S.G.M. 
For export, the value of the coal is dependent upon a number of factors, such as the supply of coal from other places and the cost of production. A report by Mr. W. H. Hunt, American consul at St. Etienne, France, is interesting in this respect. He says: "The cost of coal production in France is greater than in any other country in Europe, with the possible exception of Belgium, and it is steadily increasing, as will be seen from the following statement showing the price per ton of coal at the mines in the several countries in 1886 , 1907 and 1909 :-

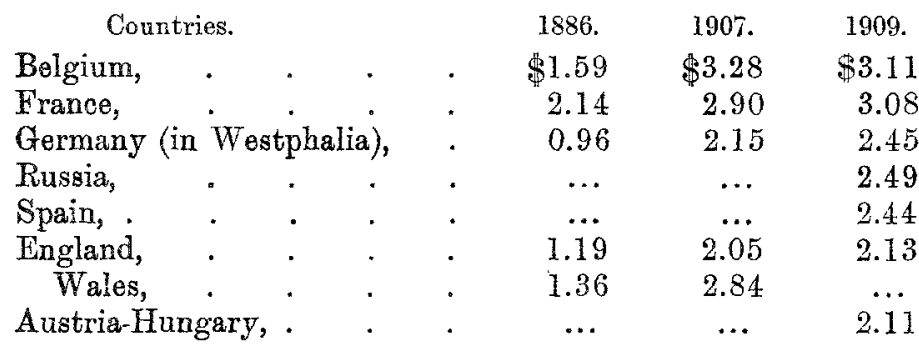

"Many reasons are advanced to explain the increasing high cost of coal production, among which the following may be mentioned. The annual output has been falling off for a number of years, in spite of the introduction of modern machinery, as the following statement showing the yearly output per miner proves:-

Countries.

England,

Germany,

France,

Belgium,
1899.

311 tons

264 ,

211,

173 ,
1908.

279 tons

246 ,

189 ,

160 ,

"The wages of the miners during the same period have steadily increased."

If the value of coal worked in a temperate climate depends upon a series of factors, much more is this the case in an Arctic one. Thus the export of coals from Spitsbergen will as a rule be possible only during about four months in the year, from June to September. The extraction, however, can be carried on during the whole year, and probably more cheaply than in Europe, as no pumping nor shoring up with timber requires to be done, the coal being found from sea-level to a height up to and above 200 metres. Wages will probably remain higher in. Spitsbergen than in Europe. The greatest difficulty in connection with coal-mining in Spitsbergen, however, is that the land is not administered by any power, but is a No Man's Land. 


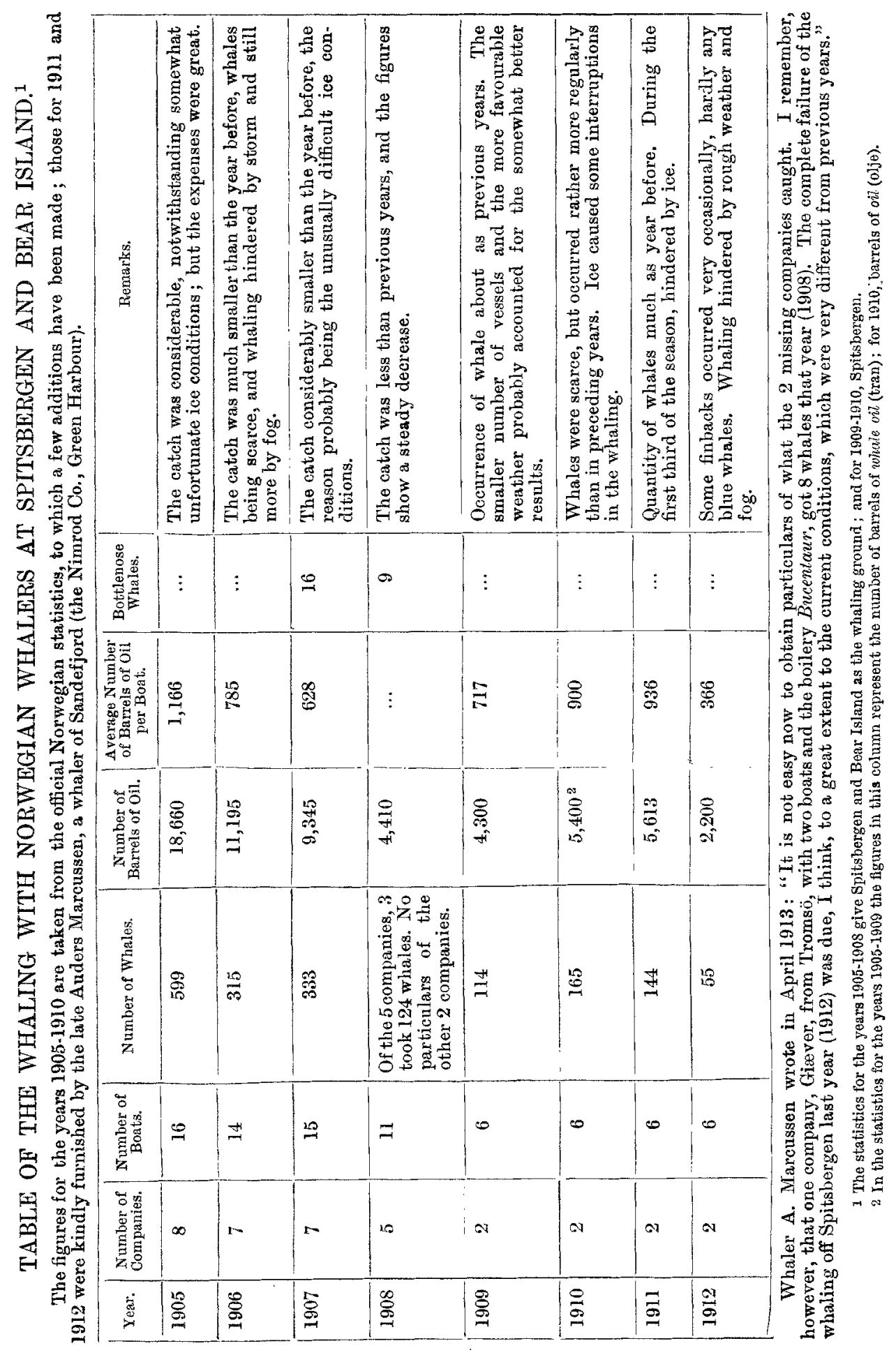




\section{Whaling and Fishing,}

Since 1901 several claims have been made in Green Harbour from which to carry on whaling. Among these may be mentioned the land round Hecla Harbour, Finnes Harbour, and Russe Keila, the lastnamed for salmon-fishing (Salmo alpinus).

Of the companies that up to 1905 were carrying on whaling along the shores of Northern Norway, two were dissolved, one went to the Färoe Isles, one to Bear Island, and eight to Spitsbergen. Seven of these eight companies had a floating boilery, and one a station on shore, at Finnes Harbour. The stations in Spitsbergen were in Horn Sound, Bell Sound, and Ice Fjord (Green Harbour and Safe Haven). One company was whaling from Bear Island from 1905 to 1908 , with a land station in Walrus Harbour. The catches of the Norwegian whalers for the years 1905-1912, both inclusive, are shown on the table opposite.

As the whaling off Spitsbergen has not been very remunerative, the number of companies has gradually diminished, and the companies have gone to other richer fields, especially in the south. Thus from 1909 to 1912 only two companies have carried on whaling from stations in Spitsbergen. After the bad results in 1912 these companies did not fish there in 1913 and 1914. The company on Bear Island had also been so unsuccessful that they gave it up as early as 1908. The station is still standing, however, in Walrus Harbour.

As the companies began work as early as May or June, they were often hindered by the ice both at Spitsbergen and at Bear Island. One great difficulty in the latter locality was the bad harbour accommodation, with constant breaking of often heavy surf.

No figures can be given regarding the results of the salmon-fishing in Green Harbour, but they cannot have amounted to very many barrels per annum. It was especially the people of the whaling-station who carried on the fishing, as it afforded a welcome change in their fare.

In the seventies and eighties of last century cod was also fished off the coasts of Spitsbergen, but this is no longer done.

\section{HUNTING.}

Round Green Harbour the stock of game is now so small that no one would think of settling down there for the winter hunting alone. Foxes there must still be, and a bear may be seen in Green Harbour in the course of the winter; but the only chance of seeing reindeer at all is by going far up the valleys. As long as it was only shot and trapped, the game lived under more or less reasonable conditions; but the use of poison has been very destructive. This reprehensible custom is all the more to be deplored from the fact that no small percentage of the animals thus killed are lost, because they creep into hiding, and die without being found. I have also heard hunters say that they have not only seen gulls die from feeding on the carcases of bears and foxes killed with strychnine, but also reindeer from eating the grass round the spot 
on which the poisoned carcase had lain. Killing by poison is now forbidden by the Norwegian Government.

It is only within the last ten years that wintering in Spitsbergen for hunting has become general. Formerly-ever since 1821-hunting expeditions to Spitsbergen were carried on with small old ships from March until well into the autumn. There are now, as stated above, few whaling vessels at Spitsbergen, which, however, is visited, as a rule, by sealers for the purpose of hunting smaller game, when they cross from the western ice to the eastern. This hunting in Spitsbergen - seal, reindeer, and the collecting of down and eggs-is rather more general than before. Sleepersharks, which are now scarcely ever fished for, were formerly also often caught. The beluga was caught-from the sixties to the nineties of last century-in the fjords and bays of Spitsbergen, Ice Fjord, Bell Sound, and Magdalena Bay; but now it is only occasionally hunted.

The value of the Norwegian hunting and fishing in the polar regions during the period from 1892 to 1911 is as follows :-

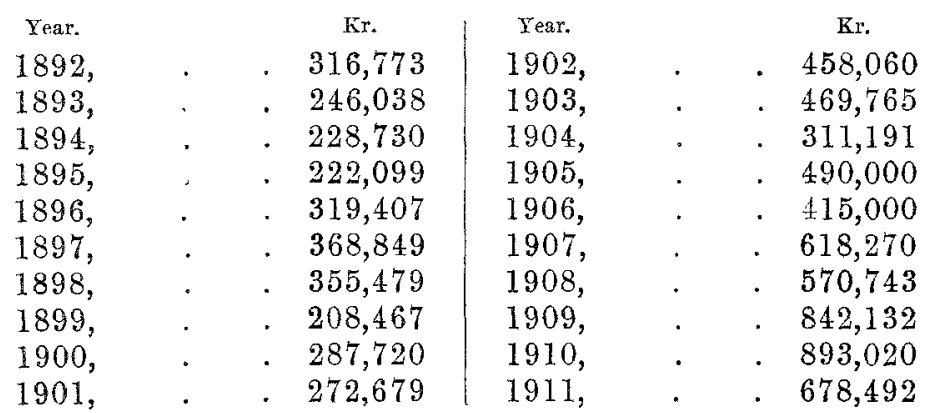

In these figures, which are taken from the Introduction to the Fishery Statistics (Norges Fiskerier, Aarsberetning vedkommende Norges Fiskerier), published by the Director of Fisheries in Bergen, the proceeds of the wintering expeditions are included. They are taken from Norsk Fizkeritidende (Bergen), where more detailed information will be found.

Many lives have been lost in the wintering expeditions, chiefly as a result of deficient equipment. The Norwegian Government has therefore been considering the institution of public control of the vessels, equipment, etc., employed in these expeditions.

During the last year or two suoh expeditions have become far less numerous. The yield has been too small. It is therefore to be hoped that the stock of game will increase. Tourists have also maltreated the reindeer in Spitsbergen, especially round Ice Fjord, often shooting the animals without making use of them afterwards.

\section{TOURIST TRAFFic.}

Green Harbour is frequently visited by tourist steamers in the summer. Formerly the vessels used always to go to Advent Bay, which is now often omitted from the tour; but most of the tourist steamers, at any rate the Norwegian boats, go into Green Harbour. It is true 
that the coal-mining in Advent Bay is at a more advanced stage; but the whaling station in Green Harbour is no less interesting. Every summer a steamer of each of the Norwegian companies, the Bergenske, Nordenfjeldske, and Vesteraalen, goes there. In 1913, for instance, on the 8th August, the first two companies' ships, Vega and Kong Harald, left Odda, in Hardanger, where they were joined by travellers from Newcastle, Antwerp, and Hamburg. On their way north the vessels called at Bergen, Geiranger, Trondhjem, Raftsund, Troldfjord, Digermulen, Tromsö, Hammerfest, and the North Cape, which last they left on 16th August. Spitsbergen was reached on 18th August, and Coles Bay, Advent Bay, Green Harbour, Virgo Bay, Cross Bay, Möller Bay, and Lilliehöok Bay were called at. The last three places are rightly considered the crowning beauties of the tour. The Norwegian tourist

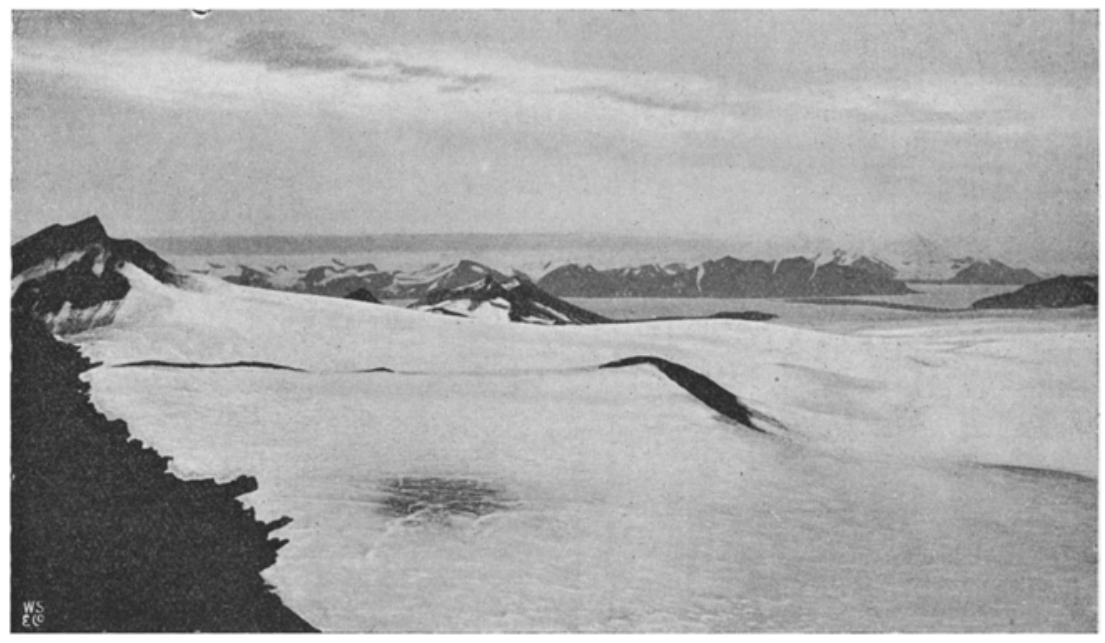

Phot. Aug. 1910.

FIG. 6. - Luoking southwards from the watershed over the Frithjof Glacier to Mijen Bay.

ships were the first to include these places in their route, and began to do so in 1908. From Virgo Bay the ships go to the pack-ice, and then run southwards along the west coast of Spitsbergen into Bell Sound and to Bear Island if the weather permits, returning to Hammerfest on the fifth day after the arrival in Spitsbergen. A week later, after calling at Lyngseidet, Tromsö, Lafoten, Torghatten, Trondhjem, Næs in Romsdal, Molde, Flaam, and Gudvangen, the ships reach Bergen, where the tour ends. In addition to the Norwegian companies, the Norddeutscher Lloyd of Bremen generally sends one of its vessels on a tour to Spitsbergen. Of late years it has been the Grosser Kurfiirst. Several other vessels are also frequent visitors to Spitsbergen, and every now and then a steam-yacht makes the tour to the islands.

The descriptive bills hold out prospects of seal, bear, and reindeershooting, but as a rule the shooting is now confined to sea-birds. The 
tours with the Norwegian ships are in great favour, largely on account of the safety that is ensured by the ships of the two companies going together. The stay made at the various places called at is very brief, indeed far too brief. Opportunity should be given to those who might desire to make excursions on shore, and thus acquire a more complete impression of Spitsbergen. There is one such excursion in particular, which has often been recommended, and which would be arranged without any loss of time for the steamer. This is the excursion from Bell Sound to Green Harbour. The steamers call at both places, and those who might like to go overland would arrive at their destination quite as soon as the ship. They might be landed on the west side of the Frithjof Glacier in Bell Sound, taking ski, snow-spectacles, and provisions for one or two days. The ship would then sail to Green

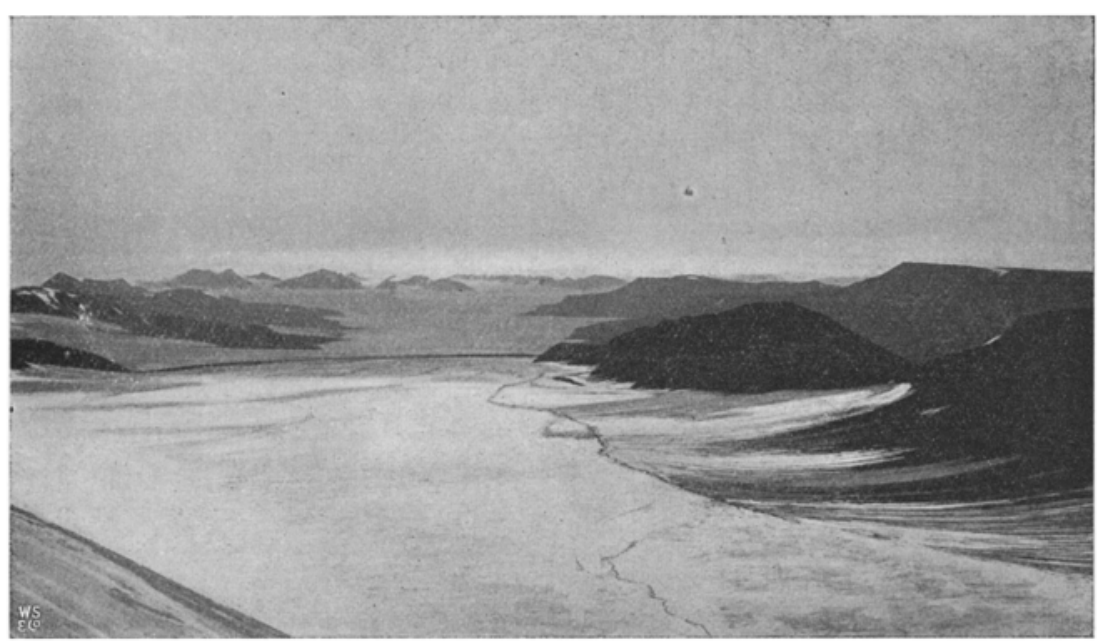

Phot. Aur. 1910.

FIG. 7.-Looking northwards from the watershed over Green Bay Glacier to Green Harbour.

Harbour, and the pedestrians go north up the Frithjof Glacier, which is as level as a road and has no crevasses. From the watershed $(400 \mathrm{~m}$. above the sea) there is a wonderful view of the typical inland scenery of an arctic land (see Figs. 6 and 7). The descent is over the Green Bay Glacier, which is also free from crevasses and easy to walk on. A large moraine separates the glacier from the head of Green Harbour, where one of the ship's motor-boats might pick up the pedestrians. The whole excursion may be done in six hours, and there is little risk connected with it, even if bad weather should occur. The ascent of one of the inland mountains might be included in the excursion.

The scenery round Green Harbour is more interesting than that of Advent Bay, as it not only presents the same formations as the latter, but also wilder scenery on the west side of the fjord, interspersed with glaciers, and the great ice-covered region in the south. 


\section{BuILDINGS.}

There are several houses and huts round Green Harbour. The Norske Spitsbergen Kulkompagni has barracks on Larvik Point (not marked on the map) and storehouses $1 \frac{1}{2} \mathrm{~km}$. farther south (Hiorth's House). Green Harbour Coal Co. has erected a house (not on the map) to the southeast of the whaling-station on Finnes, and the American company (Arctic Coal Co.) has two bouses (Longyear Villa) a little to the north of this again. Near the mouth of the fjord, the Kulkompagni Isefjord has a house (Schröder's House), and at Aust Kap (Cape Heer) there is a hut that has been erected by hunters passing the winter there.

On the west side, in Hecla Harbour, hunters from Tromsö have put up a hut, and at Russe Keila the Nimrod Whaling Company has erected a house on the west side of the river that flows from Lake Linné. (On the map the house is incorrectly marked on the east side of the river.) The largest number of houses is found on the promontory by Finnes Harbour, where the whaling-station and the Norwegian wireless station stand side by side. The position of the houses can be seen on the Nimrod Company's map (Fig. 8), which was kindly lent to me.

The whaling-station's houses are (1) the men's barracks, (2) the manager's house and kitchen, (3) the bakery, (4) the drying-house and mill for guano, (5) the flesh-boiling house, (6) the flensing floor, (7) bait, (8) boiler-house, (9) blubber-room, (10) blubber-boiling house, and (11) smithy. The wireless-station's houses are $(a)$ employés' barracks, $(b)$ temporary work-barracks (now storehouse), (c) flagstaff, $(d)$ petroleum house, $(e)$ coal and wood, $(f)$ station-building, $(g)$ backstays, $(h)$ oil-house.

The desirability of building a church in Spitsbergen has been expressed in the Norwegian daily papers. If this were done, it would probably be erected either in Green Harbour or in Advent Bay.

In this connection there is some interest in the papal decree that was signed on June 1, 1913, by Cardinal Gotti, Prefect in the "Sacred Congregation for the spread of the truth," and which shows that the Roman Catholics too will not be behindhand in extending their propaganda to Spitsbergen.

"The northerly-situated islands forming the group generally called Spitsbergen, though formerly uninhabited and even considered uninhabitable, have of late years begun to be visited regularly by many people from many countries, especially Russia, Denmark, Sweden, and above all from Norway, who come either as tourists or to carry on fishing or hunting there, or to extract the minerals that are found in many places in these islands; indeed there are not a few who have taken up their abode on these islands with their families. In order that the spiritual needs of the Catholies visiting or settled there may be in some degree eared for, and in order that the gospel may also be preached in all these remote districts, the most reverend members of the Sacred Congregation for the spread of Christianity have discussed at their meeting of the 26th May of the present year what the Very Reverend J. B. O. Fallize, the Vicar Apostolic in Norway, has recently put before

vot. $\mathrm{XxXI}$. 
this Sacred Congregation concerning the religious, as also the political and economical, conditions of those regions.

"After mature consideration of all these conditions, and with regard
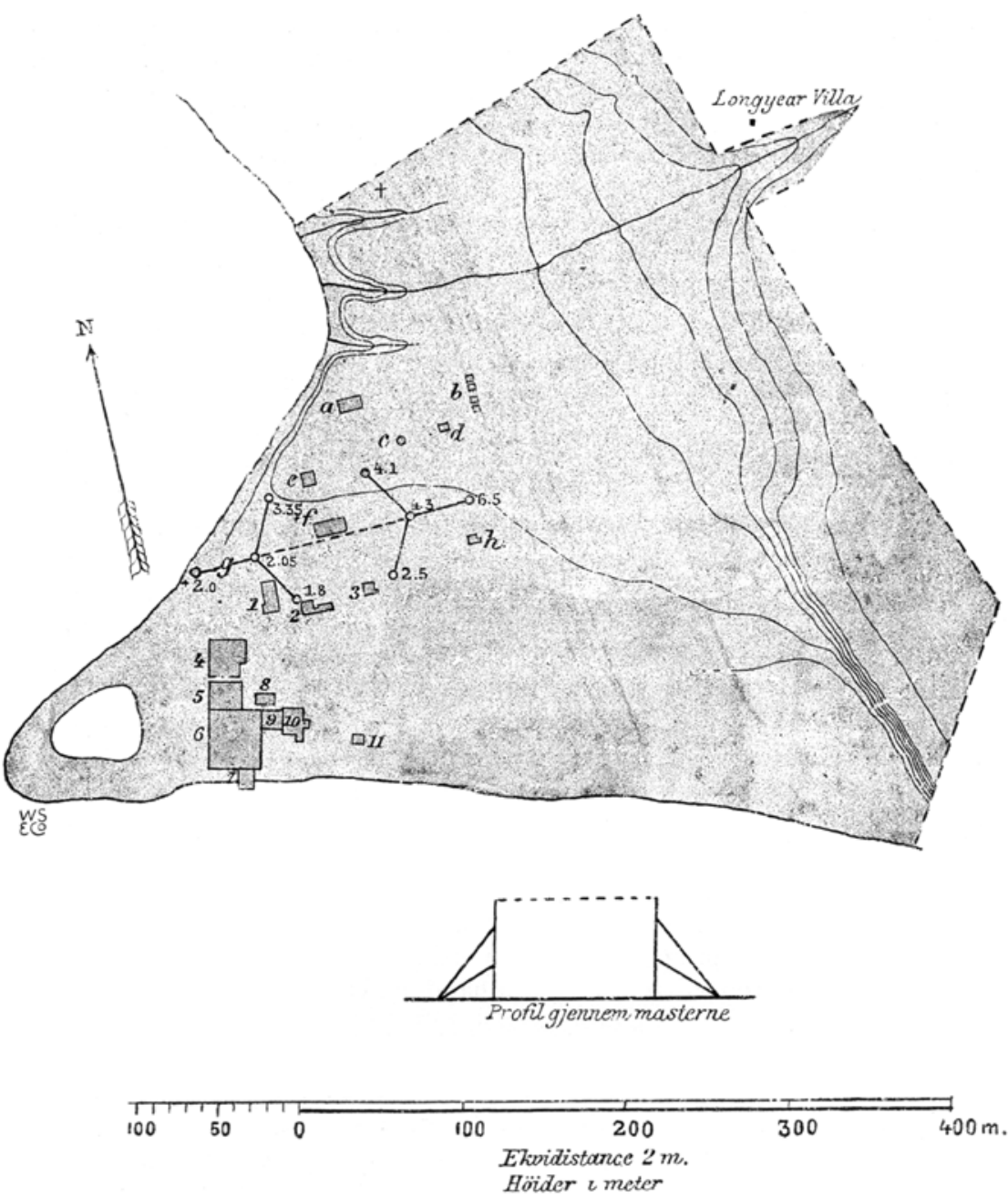

Fra. 8.-Sketch-map of the settlement at Cape Finnes.

The heights are in metres and the contour distance is 2 metres.

to what the above-named Vicar Apostolic in Norway, and the Very Reverend Albert Bitter, the Vicar Apostolic in Sweden, have proposed to this Sacred Congregation, the fathers of the Congregation have intimated their desire that the group of islands called Spitsbergen shall be combined with the apostolic vicariate of Norway, so as to form an integral 
part of one vicariate, which shall now be called the "Vicariate of Norway and Spitsbergen.'

"This proposal of the very reverend fathers was put before His Holiness Pope Pius $X$. in an audience of the 26th of the same month, by the undersigned Secretary of the Sacred Congregation, and in every particular approved and confirmed by His Holiness, who commanded that the present decree concerning this matter should be drawn up."

\section{The Norwegian Wireless Station.}

The material for this station was ordered from the Gesellschaft für drahtlose Telegraphie, the Telefunken system, through that company's representative, the electric company A. E. G. in Christiania. The buildings were ordered from the Strömmen wood-goods factory, Norway. The erection of the station was entrusted to engineer Hermod Peterson, to whom I am indebted for the following particulars. Owing to the difficult climatic conditions in Spitsbergen, allowance had to be made for a building period of about ten weeks at most; and as the object of this station was to connect Spitsbergen with the telegraphic system via Ingö radio, which is about 900 kilometres distant from the site of the intended station in Spitsbergen, the latter had to be comparatively large according to existing wireless conditions, namely, a so-called $5 \mathrm{~T}$. K. station, whereby an oscillation energy of 5 kilowatts can be produced in the antenna. The normal time for the erection of such a station was at that time about eight months. Another circumstance to be taken into account was that nothing could be obtained on the spot, so that all necessary material had to be conveyed thither. The telegraphic department hired the steamship Fanny (about 600 tons), of Arendal, for the transportation of all the material to the station. As allowance had to be made for two full cargoes, the materials had to be sent to Christiania for the loading of the first cargo, and to Tromsö for that of the second cargo. After overcoming several difficulties, the Fanny reached Green Harbour on her first voyage on the 9th July 1911. Fire broke out on board on the way north, and some materials and provisions were thrown overboard or destroyed, but fortunately no great harm was done. A site for the station was chosen on the promontory on which the whaling establishment "Nimrod," of Larvik, stands. The work of building was begun on the 11th July, and on the 20th September, after rather more than two months, the station was in working order. The number of workmen employed varied, the maximum being forty-five, in addition to fitters and the station employés. The telegraphic department furnished their board. The total of hours of labour was about 27,000 , and the average payment per hour was 75 öre. The workmen also had their travelling expenses paid both ways, with board. Only Norwegian labour was employed. The engineer of the works says that the shortness of the time taken in the building was due in the first place to the excellent body of workmen, who regarded the undertaking as a national one, each man taking a pride in contributing to the best of his ability towards the completion 
of the work before the ice shut them off from the rest of the world. There was much overtime work done. Under difficult conditions the work was done in day and night shifts. Some of the men had an average working day of thirteen hours. On the 15 th September half the detachment was sent home by s.s. Locksley, and the other half on the 20 th by the motor-smack Hella.

The Norwegian wireless station at Ingö, near Hammerfest, was temporarily completed on November 23, 1911, and on that night the first telegrams were exchanged. The line from Spitsbergen to Ingö was opened for public messages on December 10, 1911, and since that date has worked excellently in every respect. The receipts for telegrams sent by the Spitsbergen radio from December 10, 1911, to June 30, 1912 , were about $7,362 \mathrm{kr}$; and in the following year-up to June 30 , 1913 -more than $18,000 \mathrm{kr}$.

\section{The Norwegran Postal Station.}

When the Norwegian whalers, in 1905 , began whaling with Spitsbergen as their base, the post to Norway was dispatched from one of the whaling-stations in Bell Sound. When some of these, in the course of a year or two, were given up, and others moved to Ice Fjord, where the ice conditions are better, the post-office was also moved thither, the manager of the whaling-station at Finnes, A. Marcussen, being postmaster until the autumn of 1911 , when the office was taken over by the wireless station. The postal rates are the same as in Norway, Green Harbour being considered, with regard to postal matters, as a Norwegian station. Norwegian stamps are employed, and the postmark is Green Harbour. Whereas up to 1911 the post went only now and then between Norway and Spitsbergen, in 1912 a regular post was maintained between Tromsö and Green Harbour by a motor-smack. The same arrangement was continued in 1913, a hired motor-cutter leaving Tromsö for Green Harbour on June 15, July 1 and 15, August 1 and 26, and September 11, after the arrival of the express steamer, and returning from Green Harbour on June 22, July 7 and 22, August 20, and September 2 and 18. Post was also sent with the Vesteraalen Steamship Company's tourist steamer Andenes from Tromsö on August 8, returning from Spitsbergen on August 11, and with the Nordenfjeldske Company's ship Kong Harald from Tromsö on August 14, returning on August 17, and also as often as a reliable opportunity presented itself.

In old whaling times, post went to and from Spitsbergen as opportunity offered; and as early as 1623 the English maintained a special post-boat on the west coast of Spitsbergen, between the various whalingstations, from Fair Haven in the north down to Horn Sound in the south. In the seventies and eighties of last century, when the Norwegians fished for cod off Spitsbergen, the post was carried by the small steamers that went to and from the fishing-grounds. At certain of these places post-boxes were put up, which were emptied by these 
steamers when they returned to Norway. One post-box, for instance, was put up in Kobbe Bay, on the west side of Danes Island.

In 1912 more than 3700 ordinary postal packets passed through the Norwegian post-office in Green Harbour, besides a good many registered letters; and about 1000 copies of newspapers to subscribers were received at the office.

\section{Time Protection of the Fauna and Flora.}

Among the states most interested in Spitsbergen, the question has been raised as to the best means of protecting Spitsbergen's fauna and flora. Such protection is becoming more and more necessary with the increase in the number of industrial undertakings and of tourist excursions. At the conference, held in Christiania in 1912, of delegates from Norway, Sweden and Russia, it was agreed, inter alia, that occupation of parts of areas that were of special scientific interest should not be allowed. Proposals were also discussed for regulations for hunting and fishing, the employment of poison and explosives, and rules for the protection of the aretic flora.

Professor Geheimrat Conwentz, of Berlin, offered to collect declarations and proposals from authorities on the subject, to lay before the next Spitsbergen conference. Conwentz has put the following six questions :--

(1) In how far is the life of Spitsbergen worth protection and in need of it? Does the fact that Spitsbergen has no overlord place its natural monuments in special danger?

(2) What natural monuments in connection with scenery, geology, botany, zoology, have you specially in view?

(3) By what means can such protection be striven for and obtained?

(Combination for protection of special regions on land and sea; for special animals and plants; combination with steamboat companies and industrial undertakings for the carrying through of protection, etc.)

(4) Is it desirable to constitute special parts of Spitsbergen as nature reserves?

(5) What parts have you in view? (Sketch map desirable.)

(6) Have you any proposals to make in regard to the formation and maintenance of such reserves?

These questions, at the request of Professor $\mathrm{H}$. Wille, have been answered by Norwegian experts-Professor Collett, A. Hoel, J. Holmboe, Gunnar Holmsen, Hanna Resvoll Holmsen, Gunnar Isachsen, Professar Kiær, J. Sparre Schneider, and Professor H. Wille-as follows :-

"( 1 ) It must be assumed that the biological conditions in Spitsbergen will not bear any great contact with civilisation without being disturbed. The comparatively easy access to the islands enhances the danger of being exterminated run by certain endemic species. 
"On the other hand, due regard should be paid to the economic value which the Spitsbergen hunting has had for years, so that preserving shall not affect to any great extent that time-honoured means of gaining a livelihood. A restricted freedom in hunting, however, is considered beneficial to the stock of game, which it ought then to be possible to utilise more economically than has hitherto been the case.

"(2) Among geological curiosities that may require protection, we will only mention the hot springs in Bock Bay, dammed up by calcareous tufa, which were discovered by Isachsen's expedition in 1910. Among animal and vegetable species that there is special interest in protecting may be mentioned reindeer, ptarmigan, walrus, Woodsia glabella, Aira ccespitosa, var. borealis, Arctogrostis latifolia, Arctophila fulna, Glyceria Kjellmani, Carex rigida, Juncus castaneus, J. triglumis, Lusula Wahlenbergii, Tofieldia palustris, Betula nana, Alsine Rossii, Ammodenia peploides, Ranunculus glacialis, R. lapponicus, $R$. Palassii, Matthiola mudicanitis, Potentilla maltifida, Rubus channemorus, Faccinium uliginosum, Gentiana tenella, Arnica alpina.

" $(3,4,5)$ Complete protection has been suggested for the naturally well-defined area between Ice Fjord, Dickson Bay, and Wijde Bay, including Prince Charles Foreland and the sea lying within a territorial boundary of $30 \mathrm{~km}$., and in such a way that the boundary line follows a line down the centre of the above-mentioned fjords. The reason why so large a region is suggested, is that the areas on which industrial undertakings might have been begun before the protection came into force, might be excepted from the rule.

"The importation of collections of natural objects from Spitsbergen to be forbidden by the respective countries concerned. Dispensation from this rule only to be given by the governments.

"The above-mentioned plants are to be protected all over Spitsbergen. The walrus, moreover, ought also to be preserved without reservation for a period of ten years. With this exception it is not considered necessary to protect any species of animal outside the given area.

"(6) It is the duty of the international legal defence for Spitsbergen to see that the protection regulations are obeyed."

In June 1914, a new Spitsbergen conference, with delegates from all the powers interested, met in Christiania. The proceedings were interrupted, however, by the outbreak of the war, and the conference was adjourned indefinitely. 